\title{
Loving People For Who They Are (Even When They Don't Love You Back)
}

\author{
Sara Protasi
}

Forthcoming in European Journal of Philosophy ${ }^{*}$

\begin{abstract}
The debate on love's reasons ignores unrequited love, which-I argue — can be as genuine and as valuable as reciprocated love. I start by showing that the relationship view of love cannot account for either the reasons or the value of unrequited love. I then present the simple property view, an alternative to the relationship view that is beset with its own problems. In order to solve these problems, I present a more sophisticated version of the property view that integrates ideas from different property theorists in the love literature. However, even this more sophisticated property view falls short in accounting for unrequited love's reasons. In response, I develop a new version of the property view that I call the experiential view. On this view, we love a person not only in virtue of properties shaped by and experienced in a reciprocal loving relationship, but also in virtue of perspectival properties, whose value can be properly assessed also outside of a reciprocal loving relationship. The experiential view is the only view that can account not only for reciprocated love's reasons, but also for unrequited love's reasons.
\end{abstract}

\section{Unrequited Love and Reasons for Love}

What reasons does Romeo have to love Juliet? ${ }^{1}$ Love might be rationally or morally valuable in itself, but what reasons does Romeo have to love Juliet as opposed to Rosalind or another girl? In this paper I defend a version of the thesis that Romeo

\footnotetext{
* Please cite the final version.

${ }^{1}$ I focus exclusively on the psychological attitude that is called 'romantic' or 'erotic' love in the contemporary Western world. I therefore set aside historical accounts of love that are still fertile and stimulating, such as Platonic eros, Aristotelian philia, and Romantic Liebe. These notions of love do not straightforwardly correspond to our contemporary understanding of love, and so deserve a separate analysis. I thank an anonymous referee for inviting me to clarify this point. For historical surveys, see Singer 1984a, 1984b, and 1989. For an excellent review of the philosophical literature, see Helm 2009. A further clarification: when I discuss love's reasons, I am discussing reasons for love, or why love is a fitting response - in the sense of D'Arms and Jacobson 2000, 2003 - to a person's circumstances. In other words, I am not discussing reasons of love, or the reasons that romantic love gives to a person's actions. Finally, I am presupposing that there can be reasons for love in the first place. LaFollette 1996, chs. 3-4, and Kolodny 2003: 137-138, make a case for this presupposition, which is shared by proponents of the property view and proponents of the relationship view. In contrast, Thomas 1991: 471-474 and Frankfurt 2006: 36-68 argue against it.
} 
loves Juliet in virtue of the way she is, that is, in virtue of her properties. In its general form, this thesis has been defended by several authors ${ }^{2}$ and can be described as the property view of love's reasons. Niko Kolodny ${ }^{3}$ is one of the most influential critics of the view and has proposed an alternative: the relationship view of love's reasons, according to which Romeo loves Juliet in virtue of the relationship that he has with her.

Even though the two views are often seen as mutually exclusive alternatives, it is also possible to construe them as two extremes of a single spectrum. At one end, the relationship view claims that there is just one property of Juliet that grounds Romeo's love: the property of being in a relationship with him; at the other end, the property view claims that there are many more properties of Juliet that ground Romeo's love, and being in a relationship with Romeo need not be one of them. While this construal is helpful to bring out some relevant similarities between the two views, it also blinds us to important differences between them. Specifically, I will argue, there is an important difference between the views' capability to explain the phenomenon of unrequited love.

Notwithstanding his tragic end, Romeo was a lucky guy. Not only was he able to feel passionate and ardent love for a beautiful, noble, young maiden such as Juliet, but the maiden in question also passionately and ardently loved him back. Romeo was in this respect luckier than Werther, ${ }^{4}$ or the many other literary lovers who incautiously fall in love with women who cannot reciprocate their love.

Lucky indeed is the person who has never experienced unrequited love! Unrequited love is not only painful, but also quite common: who has not at least witnessed a case? Novels, plays, and movies would be without many interesting plots if all love stories were stories of reciprocated love. It is quite surprising, then, that unrequited love is mostly absent from the philosophical literature on love. This serious lacuna can be explained by the fact that most authors aim to analyze ideal

\footnotetext{
2 Most notably, by Delaney 1996 and Keller 2000.

${ }^{3}$ Kolodny 2003.

${ }^{4}$ In The Sorrows of Young Werther by Goethe. Other literary examples of unreciprocated lovers are, to name just a couple, Quasimodo (in Notre Dame the Paris by Hugo) or Mr. Farebrother (in Middlemarch by Eliot).
} 
love', that is, the best love we can aspire to. ${ }^{5}$

I am happy to concede that an ideal of love includes reciprocation. However, when trying to figure out how love works, it seems misguided to start with an idealized version. Most loves that we experience and witness are not ideal: they are messy, painful, and imperfect. Many such loves are not reciprocated. And yet, many of these loves are also grounded in reasons. In arguing for the importance of unrequited love, I am thus endorsing a normatively humble approach: I propose to look at love as it is, not as we would like it to be. Love as it is need not be reciprocated.

If we think about love from this nonideal perspective, we notice that both the property view and the relationship view, as they stand, face a significant problem that is so far unnoticed in the literature: they cannot account for young Werther's reasons. However, one view is significantly worse-off than the other. The relationship view cannot accommodate unrequited love's reasons because of a structural flaw: it does not recognize unrequited love as a genuine and valuable form of love. The property view, instead, can be amended to accommodate unrequited love's reasons. In this paper, I develop a version of the property view that does just that. Paying attention to unrequited love, then, proves doubly valuable: first, it reveals a damning flaw in the relationship view; second, it challenges us to refine and improve the property view.

Here is an overview of the paper. I start by evaluating Niko Kolodny's relationship view, which I criticize on the basis of two objections. The first is that the view inverts the order of justification between love and loving relationship, and as a consequence cannot account for unrequited love's reasons. The second is that it does not account for unrequited love's value, which lies in its peculiar disinterested appreciation of the beloved's properties. I then present the simple property view, an alternative to the relationship view that is beset with its own problems. There are at

${ }^{5}$ This 'idealistic' approach holds also for views that I otherwise mostly endorse, such as Delaney 1996 and Keller 2000, to which I refer later. For an account that is explicitly based on reciprocity, see Brown 1997. 
least three traditional objections to the simple property view, concerning the possibilities of substitutability, of trading-up, and of changes in the beloved. In order to solve these problems, I consider a more sophisticated version of the property view, which unifies existing ideas from property theorists in the literature. However, even though the sophisticated property view can answer the traditional objections, it still falls short in accounting for unrequited love's reasons. Finally, I develop a new version of the property view in response: the experiential view. The experiential view claims that we love a person not only in virtue of properties shaped by and experienced in a loving relationship, but also in virtue of perspectival properties, whose appreciation takes place also outside of a reciprocal loving relationship. The experiential view is the only view that can account not only for reciprocated love's reasons, but also for unrequited love's reasons.

\section{Relationships as Reasons: the Relationship View}

Niko Kolodny's influential view claims that every form of love consists principally in valuing a relationship, whether it is a relationship between parent and child, spouses or friends. ${ }^{6}$ In this view, the loving relationship is both the source of love's reasons and love's value. The relationship is therefore the crucial normative notion. However, this emphasis on the relationship is the source of two problematic features. First, the relationship view cannot account for unrequited love's reasons. Second, it cannot account for unrequited love's value.

Let us start with the first problem. In Kolodny's view, love for a person is justified by having a loving relationship with that person. In order to see why this is problematic, we need to consider the concept of loving relationship. A loving relationship is, in itself, different from an institutional practice such as marriage. It is first of all a volitional commitment. ${ }^{7}$ It is the expression of the lover's attribution to the beloved of a special role in her emotional life, the role of romantic partner. In the

\footnotetext{
${ }^{6}$ Given that my focus here is only romantic love, I will from now on refer exclusively to the application of his view to romantic love.

${ }^{7}$ A volitional commitment need not be a voluntary act. See Frankfurt 2006.
} 
way I define it here, it cannot be a unidirectional commitment-it must be reciprocated. I cannot bestow on someone the role of romantic partner against their will. $^{8}$

Entering into a loving relationship means committing romantically to a person. This commitment is expressed and experienced by people in different ways, which often depend on the social contexts they live in. For some people committing romantically to a person involves getting married, or being in an exclusive relationship, but for others a romantic commitment is compatible with being in an open relationship. For some people romantic commitment requires a deep concern for the beloved's welfare, to the point of putting their beloved's interests above everyone else's (including their own), but others give their beloved's interests and welfare only relative priority: their own interests, or their family's, still come first. Insofar as people have different characters, different moralities, and different personalities, love and loving relationships can take on many expressions. ${ }^{9}$

For most people, however, entering into a loving relationship corresponds to entering into a socially regulated, or even institutionalized, practice, such as dating, marriage, and the like. It is easy therefore to conflate a loving relationship with its social counterpart: a social relationship characterized by shared activities and regulated by social norms.

But there is an important difference concerning the justifications of these two kinds of relationships. In the case of a social relationship, I do not have to be in

\footnotetext{
8 Kolodny does not talk about loving relationship in quite the same way as I do. He defines a friendship or romantic relationship as an 'ongoing pattern of concern' (Kolodny 2003: 149). This definition, in the case of romantic love, is at the same time too vague and too limiting. It is too vague because a relationship between a father and a child can also be characterized as an ongoing pattern of concern, and it is too limiting because some romantic relationships do not involve much concern. Think of a man who has acquired an abusive behavior by witnessing his father's abusive behavior toward his mother: the only way he can express his love is through abuse. Or think of someone who is just plain selfish, and does not care much about the people she loves. A possible reply to such cases is that these people are incapable of loving, but this answer is driven by the idealistic approach that I reject in the first section. Although these loves are clearly defective at the moral level, they possess other characteristics of love, e.g. vulnerability to the loss of the beloved and being sensitive to reasons. A complete account of what counts as a genuine case of love is beyond the scope of this paper. 9 This claim may seem like a platitude, but it is the ignorance or underestimation of platitudes such as this that gives rise to the very narrow understanding of 'loving relationship' that Kolodny defends. Thanks to an anonymous referee for inviting me to clarify this point.
} 
love for my relationship to be grounded in reasons. There are all sorts of reasons to enter into a social relationship with someone: social duty, interest, loneliness, desire to fall in love, and so forth. These reasons are, however, distinct from love's reasons. If one were forced to marry, and so engage in characteristic activities with the spouse, one would not have on those grounds alone reasons to love the spouse. ${ }^{10}$ The same holds if one starts dating a person just because one does not want to be single anymore. A social relationship is often the context in which love develops, but it is not what can give normative ground to love.

In the case of a loving relationship, instead, the only appropriate reason to be in one is that I love that person and that person loves me back. If my love is not reciprocated, I cannot enter into a loving relationship with that person, and I experience unrequited love. Nonetheless, I may still have reasons to love that person. Furthermore, I have reason to remain in a loving relationship only insofar as I am still in love with that person, whereas I may have reasons to remain in a social relationship that are independent from love, e.g. because I want to raise my children with the other person.

Kolodny's view cannot account for this difference between loving and social relationships. This difference is important not only because it is well-grounded intuitively, but also because it allows unrequited love to have reasons. When I love someone who does not reciprocate my love, I cannot be in a loving relationship with him or her, and yet I still have reason to love him or her and I have reason to wish that they loved me back. The correct order of justification between love and loving relationship is therefore the following: I enter (and remain) in a loving relationship because I love that person, and not vice versa.

One might attempt to respond on Kolodny's behalf that reasons for unrequited love could depend on some other kind of relationship that the lover and the beloved may stand in, such as friendship. In other words, he could say that unrequited love has reasons only when those reasons are parasitic on the reasons that

\footnotetext{
${ }^{10}$ Not in a contemporary Western framework, at least. I might have prudential or strategic or moral reasons to love them. But these are different from the kind of internal reasons that we are talking about here.
} 
ground a non-romantic relationship. It would not be a full-blown account of unrequited love's reasons, but it could explain our intuition that unrequited love also needs to have reasons. Kolodny, however, cannot actually accept this explanation because he appeals to the diversity of relationships as what distinguishes different kinds of love: 'different modes of love are appropriate to different relationships. ${ }^{11}$ Parental love is different from friendship and romantic love in virtue of the different relationship that is valued. If the lover is a friend to the person she loves romantically, her friendship has reasons, but her love does not. Unrequited love is therefore necessarily deprived of reasons, according to Kolodny.

In fact, I would expect Kolodny to insist that this is the correct understanding of unrequited love. He might argue for such an understanding on the ground that unrequited love is not a valuable attitude. In fact, Kolodny talks about

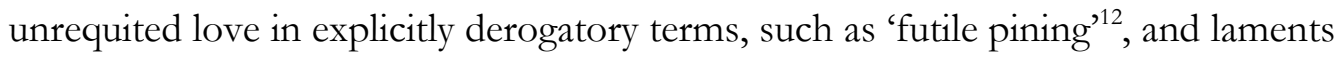
that 'our tendency to valorize unrequited love [...] reflects, in part, our admiration of perseverance in face of overwhelming odds, and, in part, our fascination, inherited from Romanticism, with unruly and immoderate emotions' ${ }^{13}$ It is therefore not unreasonable to think that his asymmetric treatment of unrequited love is based on his scarce appreciation of the value of unrequited love, perhaps on the understanding that unrequited love is not even a form of love at all. This is the second problem with Kolodny's view.

But how convincing is his picture of unrequited love as futile pining and as an example of unruly and immoderate emotion? Let me present you with a case of unrequited love that is neither unruly nor immoderate nor futile. In fact, this case shows both that unrequited love is valuable and that it is difficult to believe that while reciprocated love has reasons, unrequited love does not. ${ }^{14}$ (To help the reader follow this example and others, in each scenario the lover will always be given a name that begins with 'L' and the beloved will be given a name that begins with 'B.')

\footnotetext{
${ }^{11}$ Kolodny 2003: 147 (emphasis in the original).

12 Kolodny 2003: 171.

13 Kolodny 2003: 171.

14 Many thanks to Jeffrey Kaplan and R. Jay Wallace for pressing me on this issue.
} 


\section{Luvell and Belo}

Luvell is a gay man living in a community that rejects homosexuality, and he is in love with Belo, his best friend. Belo is heterosexual and happily married to Jamila, and does not suspect his friends' true feelings. If he knew about them, he would be disgusted and horrified, or at least this is what Luvell thinks. Luvell himself is, in fact, quite horrified: he feels in the grip of something he does not want to acknowledge. And yet, he is painfully aware of his sexual attraction to Belo, of his deep concern for him, of his appreciation for his valuable qualities. He is jealous of Belo's wife, feels sad when Belo is sad, tries to help him when he is struggling, and so forth.

Luvell is just like any other lover. There is nothing 'unruly and immoderate' in Luvell's love. ${ }^{15} \mathrm{I}$ am sure that many ordinary stories of unrequited love come easily to your mind: people fall in love with people who do not reciprocate them all the time. It is a sad fact of life that we sometimes love people who do not love us back.

Unrequited love is not just sad in the sense that it is unfortunate for those who are involved. When a lover's love is not reciprocated, something truly worthy of grief is taking place. Luvell has grasped the unique beauty of Belo and has found himself, even without realizing it, in love. This is a valuable and potentially enriching experience, thanks to its peculiar disinterested nature: Luvell loves Belo even if Belo does not, in fact cannot, love him back. I use 'disinterested' in a technical sense, not to indicate that the lover is altruistically concerned for the beloved's well-being, but rather that the lover's appreciation of the beloved is not conditional on being reciprocated, even if he longs for reciprocation. ${ }^{16}$ It is this feature of unrequited love that makes it so popular in our fictional and artistic representations of love and, pace Kolodny, appropriately so. ${ }^{17} \mathrm{We}$ admire its brave discernment: unrequited love

\footnotetext{
15 Incidentally, it is far from obvious that 'unruly and immoderate' features make love any less valuable. It is true that being unruly and immoderate is sometimes a bad thing. But it is at least an open question whether that holds for love too. Romeo and Juliet's disrespect for social rules and lack of moderation may be considered features that are valuable with respect to love, even though they lead to a prudentially undesirable outcome.

16 Thanks to an anonymous referee for inviting me to clarify this point.

${ }^{17}$ Kolodny talks about the rarity of 'unrequited noninstrumental concern' (Kolodny 2003: 171), but,
} 
makes a statement about the importance of that person, about her lovability. ${ }^{18}$ It is a response to something uniquely precious in the world, first and foremost. It expresses the capacity of attributing a special role to a person in one's emotional life without demanding that the other person do the same.

Unrequited love, then, does have value, and it is one that the relationship view cannot account for. Kolodny might still want to argue that it doesn't have reasons, but the burden of proof rests on him. In the remainder of the paper, I am going to show how the property view, in contrast with the relationship view, can be easily amended to account for unrequited love's reasons and value. In the next section, I present the most basic version of the theory, which is beset with problems that Kolodny correctly criticizes. I then proceed to show how the property theorist can reply to Kolodny's objections, but at the cost of losing the capacity to account for unrequited love's reasons. In response, I develop an original version of the property theory, the experiential view, which solves this problem.

\section{Property-Based Reasons: The Simple Property View}

Let us start with a simple case, to illustrate how the simple property view works:

\section{Lufti and Bekir}

Lufti meets Bekir. He is immediately attracted to him: Bekir is handsome, brilliant, kind and sweet. He is a witty conversationalist, a food connoisseur, and has many other qualities that make him the ideal romantic partner for Lufti. After a few months of dating, Lufti is ready to enthusiastically declare to his friends: I love him!

According to the property view ${ }^{19}$ of romantic love, Lufti loves Bekir in virtue

\footnotetext{
again, this is not what I am referring to. I am not talking about being altruistically concerned for someone's well-being.

18 Of course there are limits. If an unrequited love becomes a stubborn fixation, a lack of sensitivity to reality, or the motivation of stalking and other inappropriate behaviors, then we stop admiring it. ${ }^{19}$ What I call here the 'property view' has received other names as well. Simon Keller calls it the 'properties view' (2000), which is close enough to my label. Niko Kolodny (2003) calls it the 'quality view.' Neil Delaney (1996) does not label his view, but talks about properties rather than qualities. Robert Nozick briefly considers the property theory (in its simple form) and its problems without
} 
of Bekir's properties, that is, in this case, in virtue of his beauty, intelligence, kindness, sweetness, humor, and taste. The properties in question are all intrinsic qualities of a person. ${ }^{20}$ The property view states that in order for love to be appropriate or justified, its reasons need to necessarily appeal to the beloved's qualities. The view is appealing — after all, it seems to capture the way people often speak. (' $\mathrm{I}$ love him because he is so funny, smart and caring.') But it is subject to a number of objections, some more easily dealt with than others.

One simple objection — that the view is psychologically implausible — can be quickly dismissed. The property view does not demand that lovers have access to their reasons: Lufti may not be able to list the reasons for his love, and he may be completely misled about what his reasons are. In fact, Lufti may even present his reasons as explicitly rejecting a reference to Bekir's current properties: 'I love him because he's him. I would love him even if he were ugly and stupid'. ${ }^{21}$

Sometimes lovers make such claims in order to reassure their beloveds (and themselves) about the unconditionality and constancy of their love. Telling the beloved that they are loved per se, independently of their properties, seems to assuage the worry that love is bestowed upon them conditionally, and hence could be withdrawn when the condition is not satisfied anymore. This concern brings about three additional worries.

If Bekir+ comes along, stunningly beautiful, unusually witty, endowed with extraordinary sharpness and refined taste, Bekir might be afraid of losing Lufti's love. This is the sort of scenario envisioned by a common objection to the property theory. The trading-up objection claims that the property view implies that lovers have more reasons to love whoever has the same properties of their beloved in higher

giving it a name, and talks about 'characteristics' of the beloved (1989). I prefer talking about properties because more sophisticated versions of the property theory focus on properties that are not necessarily qualities (such as being the person who proposed to me in Manhattan).

${ }^{20}$ Nothing in the view prohibits the lover to have reasons based on qualities that are either negative (e.g. ugliness or stupidity) or qualities that are not universally recognized as positive (e.g. conservatism or spirituality), but for simplicity I will only talk about qualities that most people would consider positive.

${ }^{21}$ It seems fair to deny the lover a privileged access to his reasons for love, given that we do the same with epistemic and moral reasons. This is compatible with granting that he has privileged access to his feelings, and that any view of love's reasons needs to be phenomenologically plausible. 
degree. But we have the intuition that lovers, if they truly love their beloved, should not trade up.

A related objection is the substitutability objection, which claims that the property view is committed to saying that the lover has the same reasons for loving a certain person and for loving that person's doppelgänger (in our example, this will be Bekir*). But, the objection goes, most of us intuitively think that it would be irrational to transfer our love to someone who is qualitatively identical to our beloved. $^{22}$

A further problem for the property view is that many of Bekir's properties are fragile. What if an accident disfigures Bekir? What if aging makes him slow-witted and dull? The change objection gives voice to these concerns, contending that the property view cannot account for the intuition that we have reasons to continue to love our beloved even if he changes and loses the relevant properties. ${ }^{23}$

The simple property view easily falls prey to these objections, and authors such as Kolodny have criticized the property view on this basis. However, there exist more sophisticated versions of the property view in the literature that avoid these objections.

\section{Relational-Historical Properties: the Sophisticated Property View}

Several property theorists ${ }^{24}$ have highlighted two important characteristics of properties of persons that make them worthy of love: relationality and historicity. In this section I unify and develop suggestions already available in the literature into a

\footnotetext{
22 This is also called the fungibility objection (see Helm 2009). For some ways to answer this worry that differ from mine, see Badhwar 2003, Kraut 1986, Nozick 1989, Soble 1990, and Solomon 2002.

${ }^{23}$ Kolodny has presented versions of these traditional objections, calling them nonsubstitutability (which is equivalent to substitutability) and constancy (which corresponds to change). He also presented an original objection called amnesia. Although the amnesia objection is interesting, it is not relevant to the metaphysics of properties, the focus of this section. This objection brings out the epistemological issue of whether it is enough to propositionally know the relevant properties of the beloved to have reasons to love her. While I believe that the property view has the resources for addressing this objection, and is thus not worse-off than the relationship view in the end, I must set this separate line of inquiry aside here given space considerations. Thanks to Shen-yi Liao for a discussion on this issue. 24 See Delaney 1996, Keller 2000, and Rorty 1986. Nussbaum 1997 can also be interpreted as a qualified defense of the property view, but given its focus on Plato's peculiar version, which is especially concerned with certain valuable moral properties, I set it aside.
} 
sophisticated property view that can answer the traditional objections presented above. This view, though, only succeeds in avoiding objections by incorporating the valuable insight contained in Kolodny's view, the importance of the relationship. Consequently, the sophisticated property view ends up inheriting the relationship view's problem with unrequited love.

\subsection{Substitutability and Trading-Up}

The substitutability objection says that, according to the simple property theory, if Lufti is presented with Bekir*, a doppelgänger from another world, he will have the same reasons to love him as he has to love Bekir.

Some may not find this implication disturbing. ${ }^{25}$ But if you do, then the property theorist owes you a response. Reasons for love should not be easily transferable, and the property theory in its simplest form seems to imply that they are. Kolodny is onto something when he says that the relationship that holds between the lover and the beloved is relevant to the lover's reasons for love.

According to the property theorist, Lufti's love for Bekir is grounded in the properties that determine what kind of person he is, what we would normally call his qualities. ${ }^{26}$ Ideally, when Lufti is asked what his reasons for loving Bekir are, he will talk with appreciation and gratefulness for all the ways in which Bekir's qualities lead to their flourishing relationship.

Earlier I mentioned beauty, intelligence, sense of humor, sweetness, kindness, and taste. These are all lovable traits on paper, but they are also quite generic. It is from this understanding of properties in generic terms that most objections arise. Properties that are going to be mentioned when Lufti tells us why he loves Bekir must be far more specific than this to count as appropriate reasons, and will crucially involve their relationship. Bekir's properties are experienced by Lufti in the intense interaction constituted by their relationship.

25 See for instance Lamb 1997.

26 Any adequate version of the property theory is best interpreted as making a claim about the necessity of appealing to the properties of the beloved to ground love, but not about the exclusivity of those reasons. Reasons for love necessarily need to appeal to how the beloved is, but there could be other reasons as well (such the fact of having a family together). 
By 'relationship' here I mean reciprocal interaction in the context of a loving relationship and (most of the time) of a social relationship as well: two individuals engage with each other though shared activities and different forms of communication that are shaped by a common understanding of what their relationship is about. This interaction takes place both before and after entering into a romantic relationship. ${ }^{27}$

Lufti loves Bekir because Bekir knows how to treat him when he is in a bad $\operatorname{mood} ;{ }^{28}$ he loves him because of a certain kind of sweetness that Bekir reserves only for him; and so on for many of the other properties that ground Lufti's love. Many of Lufti's qualities, then, are relational properties.

As I see it, a property can be relational in two senses. In one sense, a property is relational when its existence or instantiation depends on the existence of the relationship. The property of being nice to Bekir when he is in a bad mood requires for its existence that Lufti be in a relationship with Bekir. Another example would be the property of being sweet to Lufti, if Bekir is sweet exclusively to Lufti and to nobody else: it is a property that would not be instantiated were it not for the relationship with Lufti.

We can also talk about relational properties in a wider sense: a property that can be experienced in idiosyncratic and peculiar ways in virtue of an existing relationship. Suppose that Bekir's sweetness is an intrinsic, or nonrelational, property of him. However, the way he is sweet to his mom is different from how he is sweet to Lufti. Bekir's sweetness is therefore relational in the sense that different people experience it in different ways. ${ }^{29}$

Many of Bekir's intrinsic properties are experienced relationally by Lufti. These relational properties are what make Bekir lovable in Lufti's eyes because they

\footnotetext{
${ }^{27}$ Notice that these are still reasons that stem from a person's properties, only mediated by, and experienced within, the relationship. So it is not the case that the relationship precedes love, as in Kolodny's view. Thanks to an anonymous referee for asking me to clarify this point.

28 This example is in Keller 2000: 166.

29 This wider sense is not completely trivial, however. Some properties are just non-relational, such as being 5 ' 6 " tall, or living on the third floor. These properties are also unlikely to ground love. Being taller (or shorter) than the lover, on the other hand, is a relational property, which may play a role in grounding love, together with other qualities of the person.
} 
are what make Bekir who he is in Lufti's presence. But there is more: being in a relationship with Lufti will affect Bekir's identity in a further way. Bekir's properties will change through time thanks to the loving relationship. Not only that: Lufti's properties too will be affected by the relationship, and the changes will multiply in the same way as a pebble thrown in a puddle creates a ripple that creates others, which in turn create many more. ${ }^{30}$

By loving and being loved, we change continuously. The properties of a person are not only experienced in the relationship, but they are also shaped by the relationship. A property theorist who incorporates relational features into properties can therefore agree with Kolodny: my being in a relationship with a person is quite relevant to my reasons for loving her. But the agreement ends there. Being in a relationship is relevant only in an indirect and mediated way: my relationship with that person affects the way she is, the way I see her, the way she changes, and the way I change. ${ }^{31}$ Consequently, properties that ground my love are thus affected by how those properties have been experienced in, and changed by, our relationship. Nevertheless, it is necessary to appeal to those properties in order to show that my love for that specific individual is justified. The relationship itself is not the ground of my justification: the person and her properties are. A loving relationship just happens to be the context in which most lovers experience the beloved's properties. But it need not be, as we will see when we return to unrequited love.

We can now see how the sophisticated property view can answer the substitutability and a fortiori the trading-up objection. Neither Bekir+ nor Bekir* can endanger Bekir's place in Lufti's heart, because neither has the same relational properties of Bekir, and therefore neither can be automatically considered for

\footnotetext{
30 Amélie Rorty articulates and depicts particularly well the tight connection between a person's properties and how they are affected in a loving relationship. She proposes an ideal of love that is 'dynamically permeable. It is permeable in that the lover is changed by loving and changed by truthful perception of the friend. Permeability rejects being obtuse to change as an easy way of assuring constancy. It is dynamic in that every change generates new changes, both in the lover and in interactions with the friend.' Rorty 1986: 402, emphases in the original.

31 Another way of putting the same point is this: properties such as being in a relationship with, being my partner, and being the person I have been married to for twenty years are only secondarily important. They enter into love's reasons only insofar as having those properties causes one to have also other properties, which directly constitute the way the beloved is with the lover.
} 
substitution. That is, the sophisticated property view can account for the widespread intuition that Lufti does not have the same reasons to love Bekir* or Bekir+, even though these people might qualify as future objects of Lufti's love. Lufti might have reasons to love many other people, but there is no risk of easy substitutability or of trading-up because Bekir* and Bekir+ are in fact quite different from Bekir, and so loving them needs property-based reasons of its own. That reasons for love cannot be automatically transferred from Bekir to Bekir* does not imply that there cannot be reasons for Lufti to one day love Bekir* (or Bekir+). No adequate theory of love's reasons should deny the possibility that love ends. Lufti could one day fall out of love with Bekir and fall in love with someone else. But if this happens, according to the view defended here, it is because of a change in Bekir's properties such that they cannot ground Lufti's love anymore. ${ }^{32}$

\subsection{Change}

The change objection is an even stronger case against the simple property theory because it is quite realistic: we do not have to wait for a doppelgänger or a 2.0 version of Bekir to show up, given that people can just lose their properties. Many of Bekir's attractive properties are fragile. He may lose his beauty, his quickness, his sense of humor, his taste. Shouldn't love resist these alterations?

Intuitions, even more than in the previous case, may differ, and rightly so.

After all, we do see lovers falling out of love when their beloveds age and change, and they might be able to defend their reasons convincingly. But we also see many who do not fall out of love when change happens, and it does not seem right to say that those lovers are expressing inappropriate attitudes. ${ }^{33}$ The sophisticated property

\footnotetext{
32 There might be other reasons why Lufti's love ends: for instance, his preferences about lovable properties may change, in which case Bekir's unchanged properties might become a reason for love to end, not to continue. That people's preferences and values change over time is compatible with the property view. Interactions between lovers affect the lovers' values and preferences, which is why successful relationships are those in which lovers change together and in accordance with shared values. For reasons of simplicity, I will assume throughout that the lover's most important preferences stay constant. Thanks to an anonymous referee for asking me to clarify this point.

33 An alternative answer to the change objection is that love is grounded in the new properties of the beloved. Say at T1, before the change has occurred, Lufti loves Bekir in virtue of P1, P2, P3 (non-
} 
view responds to this concern by highlighting the historical character of relational properties. $^{34}$

Relationships take place in time. Bekir knows how to treat Lufti when he's in a bad mood because he learned how to do it through the many difficult moments they faced together. Being in a relationship offers the advantage of witnessing changes and having the chance to adapt to them. Properties are relational-historical when, in order for them to be experienced, the lover must have spent a considerable amount of time with the beloved. ${ }^{35}$ Properties can therefore be experienced as they change.

Notice that there is also a different sense in which a property can be said to be historical: properties can characterize a person with reference to some date or event that takes place in time, such as being born on $05 / 21 / 1978$ or being born in Casablanca. These properties in themselves may seem irrelevant for love's reasons. They do, however, become relevant, in the context of a loving relationship: that Bekir was born on May 21st is relevant to Lufti, who is an amateur astrologist and believes that a Gemini is his ideal match. Similarly, that Bekir was born in Casablanca is relevant to Lufti who was also born in Casablanca, and finds important that he and Bekir grew up in the same streets, speak the same language, and so forth. Properties of this kind concern the history of the beloved, contribute to create a bond with the lover, are especially significant to the lover, or affect how the lover perceives the

historically experienced). At T2 a change occurs, such that Bekir loses all of those and acquires P4, P5 and P6. Lufti can love Bekir in virtue of those properties instead. Would this be problematic, even for the simple property theory? If not, then there is no need to talk of historicity. A different version of this answer would be that Bekir loses just P1 (say, beauty) but acquires P4 (say, empathy). Thanks to the acquisition of the new property, Lufti has as many reasons to love Bekir as before. I think the first version of the proposal is implausible: if all properties that ground love are lost, then love is not fitting anymore. But a version of the second answer works. What happens when love is constant is that properties grounding love overlap: there is a standing core of properties, which allows for some properties to gradually become less relevant and be substituted. When they were younger, Bekir's beauty was very important to Lufti. As they grow up, other properties of Bekir become the ground of Lufti's love, such as his sympathetic attitude toward other people and his bravery in dealing with hardships. Notice that this answer does rely on highlighting the historical dimension of a relationship. Thanks to Tamar Szabó Genlder for stimulating my thoughts on this point.

34 Thanks to an anonymous referee for helping me to greatly simplify my treatment of the historical character of relational properties.

35 Thanks to Matthew Smith for help on this formulation. 
beloved. If some historical property makes the beloved special to the lover's eyes, then that property can be involved in his reasons for loving the person. So for instance Lufti might love Bekir because he has these historical properties: being present at his father's funeral, playing together in the Ain Sebaa team in the Eighties, being born in Casablanca in 1978, and so on. There can be many other historical properties by virtue of which Bekir is special to Lufti. ${ }^{36}$

We can now see how the historical character of many relational properties allows the sophisticated property theorist to answer the change objection. While some of them are unaffected by change (Bekir will always be the one who was Lufti's soccermate), others can adapt to change: Bekir's personality and appearances evolve through time, so what the property of (Bekir's) beauty refers to is different at 18, at 35 , and at 60 .

Sometimes properties are not experienced historically in a way that guarantees the survival of love. Thinking about constancy in the face of change naturally leads to thinking about what happens when change justifies reasons to fall out of love. If Lufti falls out of love with Bekir, his reasons have to be as discerning as before: they need to refer to what Bekir is or is not- that is, to his relationalhistorical properties.

The sophisticated property view is not committed to the claim that any change in the beloved's properties will end a love, nor should it be. When people talk of 'unconditional love', they express a wish that is not always legitimate. Loving should not create the same bond that naming, for instance, creates: it should not be the case that we love unconditionally, since we may have reason to fall out of love. This is a straightforward consequence of the claim that love has reasons: if we believe that falling in love has reasons, and remaining in love has reasons, then also falling out of love must have reasons.

If, for instance, the beloved is not recognizable as the person we fell in love

\footnotetext{
${ }^{36}$ Neil Delaney has some other nice examples, such as having been dance partners at a specific social event, or being the person who proposed to you in Paris (Delaney 1996: 346).
} 
with, it is appropriate that our attitude tracks that change. ${ }^{37}$ This is not a far-fetched case. People who develop drug-addiction or depression or who experience a traumatic or life-changing event (such as going to war or religious conversion) may change radically and suddenly. ${ }^{38}$ Sharing a history within a relationship does not and should not guarantee that love will survive at any cost. The same may happen if it is the lover, Lufti, who changes radically: the way he interacts with Bekir will be different and Bekir's properties will be affected by this change. ${ }^{39}$

The sophisticated property view can then answer all the traditional objections. But it does so by incorporating properties shaped by a loving relationship - that is, by the very reciprocal commitment that unrequited love lacks. It seems that the sophisticated property view cannot account for unrequited love's reasons, as it stands. In the next section, I develop the experiential view, which incorporates a further refinement of the property view. ${ }^{40}$

\section{Perspectival Properties: the Experiential View}

Let me start with the concession that the sophisticated property view is not quite hopeless. Unrequited love does not always take place in the absence of any kind of loving relationship. It is in fact common for unrequited love to take place within the context of friendship. In such a case, we could still have relational-historical properties. Kolodny does not have this way out, because according to his view different kinds of relationships correspond to different modes of love. The property view, however, does not suffer from such limitation, since it grounds love's reasons in the beloved's properties.

${ }^{37}$ Kolodny acknowledges this as well. See Kolodny 2003: 165.

38 This is a case where the lover cannot be affected by the change in a positive way, that is, cannot change together with the beloved. The gap is too radical to even try to share the change. Also, as Rorty observes, there are limits to how much our identity is affected by loving a person, because 'a person's previous traits resist transformation' (Rorty 1986: 403).

39 They might still have reasons to love each other in a friendly or affectionate way, and there might also be one or more reasons to remain in a social relationship, for instance, to remain married (for the children's sake, for economic reasons, for religious reasons, to preserve a public image, and so forth).

40 Thanks to Michael Smith for a useful discussion on possible names and, more importantly, on the content of my view. 
Friendship and romantic love are interpersonal relationships characterized by intimacy and symmetry that allow relational-historical properties to develop. However, it is also possible for love to develop in the absence of friendship. Consider the following case.

\section{Luigi and Brigitte}

Luigi is French actress Brigitte Bardot's butler. He has been her faithful servant for many years. He is deeply, hopelessly in love with her. He has never been deluded about his situation. She is beautiful, famous, rich, and surrounded by handsome and powerful men. She appreciates Luigi's service and she treats him well. She is unaware of his love, since he has always behaved professionally and kept his impersonally courteous manners. While he knows her very well, she does not know him very well. Being very self-centered, she does not pay much attention to those who are not in her circle of friends and family. Their relation is very asymmetrical, not just in terms of emotional intensity, but also in terms of the quality of the interactions, the kind of knowledge that they possess of the other and the kind of intimacy they have with each other. Luigi is very attentive to Brigitte's needs and emotions; he knows what she likes and dislikes, and what makes her nervous or excited; even though she has never seen him in a situation of personal distress or lack of decorum, he has taken care of her when she was sick or distressed.

This seems to be a case of genuine love. If that is correct, then Luigi has reasons to love Brigitte that are resilient. he has reasons to not easily trade-up, to not love Brigitte's doppelgänger, and to not fall out of love when some of Brigitte's properties change. But there is no loving, reciprocated relationship, not even of a friendly kind, that can account for his reasons. We need a new kind of property that can do the work.

\subsection{Perspectival Properties}

From Luigi's story, we gather that we can love a person in virtue of her properties even in the absence of an intimate relationship. This is because some of the properties that ground love are perspectival. Perspectival properties depend on the 
response of the subject - their existence is dependent on the subject's perspective. The clearest case of such a property is beauty. ${ }^{41}$ When I say I love a person in virtue of her beauty, I am saying that I love her in virtue of the fact that she looks beautiful to me. In the same way that a cube can appear three-dimensional to me but twodimensional to you because we are looking at it from different perspectives, so the same person can appear beautiful to me but quite plain to you.

Perspectives may differ depending on several factors. However, nothing precludes two persons from sharing the same overall judgment of beauty, in the same way that you and I can be in almost the same place and so have roughly the same view of the object. Even then, how the object appears to you will necessarily be different, albeit minimally, from how it looks to me in virtue of our different perceptual systems. The same holds for beauty: the different views depend not only on where we stand with respect to the person but also on our standards of beauty, standards which are determined by many different factors and whose combination is idiosyncratic. Sense of humor is another clear example of perspectival property for similar reasons.

In the context of a reciprocated loving relationship, beauty and humor are also relational-historical, insofar as they can be experienced in, and shaped by, the relationship. But in the case of unrequited love, humor and beauty may be understood only as perspectival. Furthermore, many qualities that we are used to considering as non-perspectival (such as intelligence) can be experienced perspectivally too. ${ }^{42}$

A view that incorporates relational, historical, and perspectival properties can be called experiential because these properties could not exist or be experienced without the lover having interacted with the beloved, where interacting means

\footnotetext{
41 The idea of perspectival properties can be readily found elsewhere in philosophy, of course, but the application of this idea to a theory of love's reasons is not.

42 As an example of a property that is not narrowly perspectival consider intelligence. While there are objective standards of intelligence, it can be experienced perspectivally: my intelligence will be experienced differently by my 10 -year-old cousin and by Albert Einstein. This is not to say that any property is perspectival or can be experienced perspectivally: being tall 5' 8 " and living at a certain address, for example, are not perspectival in either way.
} 
experiencing a person's traits in a way that does not need to be reciprocated. The interaction in most cases takes place in person, but it need not: sense of humor, for instance, can be experienced in an email exchange or even via some other medium, such as a TV recording. ${ }^{43}$

For the appreciation of properties such as beauty and humor, even only a few interactions will suffice. ${ }^{44}$ For properties like intelligence, more interactions may be needed. (A person who is more intelligent than I am can happen to say stupid things when I am around.) In the absence of such familiarity, the only available description of the person will assume the contours of a grocery list. ${ }^{45}$ The picture we can have of a person in that case is flat and unidimensional, and it will be a sum of generic traits, generating a description that could apply to many others.

\subsection{Classical Objections and Unrequited Love}

We can see how perspectival properties help the property view to handle the traditional objections also in the case of unrequited love. Even in the absence of a

43 Thanks to Tamar Szabó Genlder for pressing me on this point.

${ }^{44}$ Here I mean to only sketch an account that needs to be refined in a separate paper. One might object, for instance, that one interaction is sufficient to experience beauty or sense of humor. (I owe this objection to Matthew Smith). But people do not always appear at their best (or their worst), and first impressions can be mistaken. To be certain of having experienced a person as she truthfully is, even in a perspectival sense (that is, as she truthfully is to me), multiple interactions seem necessary. This holds furthermore for properties that are dispositions: moral integrity, or coherence, for instance, cannot be experienced in one interaction. (I owe this example to Eric Guindon). A related objection would be that intelligence does not differ from beauty: I can be wowed by someone's brilliant remark as much as by her spectacular looks. (I owe this objection to Pamela Corcoran). I agree that it is possible, but I do not think it is typical: typically it takes less time to experience beauty than intelligence (though incidentally, sometimes it takes a while to experience someone's beauty, too). A further complication is added by the fact that interactions differ in quality: an intimate and intense conversation between two people may count as one interaction, but the experience could be quite different from talking to someone during a group discussion of professional issues.

$45 \mathrm{It}$ is hard, if not impossible, to specify in abstract how many interactions, or what kind, would count as sufficient for a truthful appreciation of properties. One reason is that people vary with regard to perceptiveness, capacity to accurately judge a person, levels of intimacy and so forth. It may be possible to come up with more pragmatic criteria, such as possessing the ability to predict the person's behaviors or reactions, or possessing the ability to describe her character in ways that are assessed as accurate by more intimate friends. However, such criteria are unlikely to perfectly track the distinction between being superficially acquainted with someone and knowing them. For example, we may know a person very well, but still fail to predict her behavior in many circumstances. Nevertheless, I trust that we have an intuitive grasp of this distinction. Thanks to an anonymous referee for pressing me on this point. 
relationship, perspectival properties can account for the uniqueness of the beloved. The beloved's properties are not generic, because they are perceived through my perspective and my perspective is shaped by the unique interaction I have with that person. The lack of reciprocation does not impede the unique interaction between valuable features of the beloved and the idiosyncratic perception and appreciation of those features by the lover. The lover therefore still has reasons for loving that person rather than someone else, provided that she has had a sufficient number of interactions such that she indeed has a perspective that goes beyond a superficial description of the beloved's properties.

The interactions that characterize unrequited love in the absence of a personal relationship in themselves will not suffice to create the kind of relationalhistorical properties to which sophisticated property theorists appeal in order to justify the fact that the beloved cannot easily be substituted. ${ }^{46}$ Perspectival properties stand in for relational-historical properties in this respect, provided they can answer the following objection: Don't perspectival properties involve some sort of projection on the part of the beloved of his or her own expectations and fantasies? If such a projection took place, the beloved's uniqueness could not be guaranteed, because in principle the lover could apply the very same 'mold' to anyone. ${ }^{47}$

The answer to this objection has to be nuanced. First, it is important to keep in mind that the danger of projection lurks in every human interaction, including reciprocated love. Relational-historical properties do not guarantee an absence of projection: we can project desired properties that a person lacks on someone with whom we are in a relationship as well as on someone with whom we are not.

Second, there is no reason to think that having a perspective means simply imposing one's schemata to the point of radically ignoring reality. When I perceive an object, that object has some primary qualities that cannot be altered by my perception and that affect the experience I have of it. Also in the case of people,

\footnotetext{
46 Relational-historical properties, however, will be experienced by those unreciprocated lovers who romantically love a friend.

${ }^{47}$ I would like to thank Gary Foster for bringing this up and so reinforcing my own conviction that this issue is well worth addressing explicitly.
} 
perspectival properties need not be grounded in fantasies. Even if Luigi experiences Brigitte's charm with men only indirectly, when he witnesses her interactions with her friends and lovers, he still experiences it.

Also, Luigi's love is grounded in many of Brigitte's properties. It is possible that he does project some qualities onto her. He might think of all his female employers as charming. He did think of his previous employer, Italian actress Sophia Loren, as very charming. This certainly does not suffice to make Sophia and Brigitte interchangeable. Unless Luigi is delusional, in which case there is a problem with relational-historical properties as well, the many other properties that Brigitte and Sophia possess will affect the perspective that he has of these two different women.

That perspectival properties depend more heavily on the lover's psychological make-up is undeniable, but this is not bad news for the experiential theory, since it predicts that in a case of unrequited love the beloved will be more easily substituted and that trading-up will take place more frequently. This seems not only a correct prediction, but also a normatively appropriate outcome. Thanks to his unique perspective of Brigitte, Luigi has reason to love Brigitte, even if their relationship lacks reciprocal intimacy and knowledge. That Luigi has reasons to love Brigitte, however, does not mean that his love is equal in all respect to reciprocated love. It is not possible for Brigitte to be authentically affected by Luigi and she remains an overall passive object of attention, appreciation, and love. Their interaction is too weak to create the 'ripple effect' that I described earlier. As a consequence, unrequited love is, as a rule, less resilient than reciprocated love.

Reasons for love might be balanced or outweighed by prudential reasons to fall out of love, and this holds especially in the case of unrequited love. If one cares about being reciprocated he will have reasons to starve his love and try to fall out of it. Unrequited love tends to trigger its own end. It tends to be less constant, even though some unrequited loves last for a long time, as in Luigi's case. When unrequited love lasts, it does so by surviving the changes that occur in the beloved, thanks to the fact that a core of lovable properties, experienced perspectivally, survives and grounds love. Cases where unrequited love is constant despite the lack 
of some kind of personal relationship may be rare. ${ }^{48}$

\section{Conclusion}

In this paper I argued that the recent debate on love's reasons has been ignoring an important problem: unrequited love. Unrequited love can be as genuine and valuable as reciprocated love. Therefore any adequate account of love's reasons needs to account for unrequited love's reasons as well. I showed that, of the two popular views that are often contrasted - the property view and the relationship view- the former can accommodate unrequited love's reasons with an important modification, whereas the latter cannot do so at all. Looking at the debate from the point of view of unrequited love provides further support to the property view, appropriately amended.

As I foreshadowed at the beginning, the analysis of the different versions of the property view shows that the contrast between these two theories is not as stark as it may seem at first. On the one hand, sophisticated versions of the property theory incorporate relational features. On the other, the relationship view can be seen as a version of the property view, one that takes the property of being in a relationship with the lover to be the only important property. ${ }^{49}$

Convergence between extremes is a sign of maturity of a philosophical debate. ${ }^{50}$ However, I believe that focusing on the similarities between the two views obfuscates useful distinctions. What ultimately matters to the advocates of the relationship view is that there is a loving relationship that holds between two people.

\footnotetext{
48 This is consistent with the fact that it is harder to fall out of unrequited love if the lover remains in some sort of relationship with the beloved, which is why we suggest to lovers who want to fall out of love that they eliminate every source of contact with the beloved.

49 Thanks to Raymond Critch, Matthew Smith, and Zoltán Gendler Szabó for inviting me to address this way of reframing the question.

${ }^{50}$ A forthcoming article by David Wong summarizes elegantly and rigorously the state of the debate, argues convincingly as to why the extreme approaches are unsatisfying, and represents in itself an exemplary case of a more nuanced position. His view advocates for a pluralistic conception of love, which requires a pluralistic understanding of its reasons or lack thereof, and thus integrates not only the property and the relationship views, but also the view according to which love has no justificatory reasons. Even though he shares my uneasiness with what I called "idealistic" approaches to love, he (surprisingly) does not devote particular attention to unrequited love. See Wong 2014.
} 
This is the reason why love is appropriate or justified, and the reason why it is valuable. For the proponents of the property view, in all its forms, what matters is another fact: that the person who is loved has certain lovable characteristics, and therein lie the reasons for love's appropriateness, and the source of love's value. If we look at the debate from this angle, what is significant is not that both views refer to some property to ground love, but that they embody two very different weltanschaunng: the relationship view sees love's reasons as grounded in relationality, whereas the property view sees them as grounded in individuality.

This different perspective on love determines different approaches to a variety of specific issues, including but not limited to the value and rationality of unrequited love. For instance, a view that focuses on the relational character of love is prone to look for the valuable features of love in a successful, harmonious relationship that leads to the happiness and possibly the moral flourishing of the two lovers. A view that focuses on the qualities of the beloved will be content with the lover's appreciation of the lovable features of a person, which of course might be not seen as lovable by an external observer. The property view is therefore more likely to approach love from a normatively humble perspective, according to which a good instance of love is not an instance of ideal, reciprocated love, but rather requires only that someone found someone else lovable. The more the property view becomes sophisticated, the less naive its outlook on reality is; what is worthy of love is, maybe, only what is experienced as lovable to me.

It may still be worth experiencing, as long as it lasts. ${ }^{51}$

\footnotetext{
${ }^{51}$ For valuable criticisms, comments, and suggestions to this and previous versions of this paper, I would like to thank all the anonymous referees that provided valuable comments, and also: Stephen Darwall, Tamar Szabó Gendler, Chenyang Li, Matthew Smith, Dustin Tucker, the participants to the Yale Work in Progress seminar in Spring 2011 (in particular Pamela Corcoran, Zoltán Gendler Szabó, and Barbara Sattler), and the audience at the Leuven Reasons of Love conference (in particular Kate Abramson, Raymond Critch, Gary Foster, Alexander Jech, Diane Jeske, Jeffrey Kaplan, Adam Leite, Jerrold Levinson, Michael Smith, R. Jay Wallace, and Nick Zangwill). Special thanks to Michael Della Rocca, Eric Guindon, and Shen-yi Liao for extensive discussions. Many thanks to Catherine Chamberlin and Dustin Tucker for their editorial help.
} 


\section{References}

Badhwar, N. K. (2003), 'Love.' In H. LaFollette (ed.), Practical Ethics. New York: Oxford University Press.

Brown, D. (1997), 'The Right Method of Boy-Loving', in R. Lamb (ed.), Love Analyzed, Boulder: Westview Press.

D'Arms, J. and Jacobson, D. (2000), 'The Moralistic Fallacy: On the 'Appropriateness' of Emotions', Philosophy and Phenomenological Research, 61 (1): 65-90.

D'Arms, J. and Jacobson, D. (2003), 'The Significance of Recalcitrant Emotions (or Anti-Quasijudgmentalism)', Philosophy, 52: 127-145.

Delaney, N. (1996), 'Romantic Love and Loving Commitment: Articulating a Modern Ideal', American Philosopbical Quarterly, 33 (4): 339-356.

Frankfurt, H. (2006), Reasons of Love. Princeton: Princeton University Press.

Helm, B. (2009). 'Love.' The Stanford Encyclopedia of Philosophy (Fall 2009 Edition), Edward N. Zalta (ed.), URL = $<$ http://plato.stanford.edu/archives/fall2009/entries/love/>.

Keller, S. (2000), 'How Do I Love Thee? Let Me Count the Properties', American Philosophical Quarterly, 37 (2): 163-173.

Kolodny, N. (2003), 'Love as Valuing a Relationship', The Philosophical Review, 112 (2): 135-189.

Kraut, R. (1986), 'Love De Re', Midwest Studies in Philosophy, 10: 413-30.

LaFollette, H. (1996), Personal Relationships: Love, Identity, and Morality. Hoboken: Blackwell Press.

Lamb, R. (1997). 'Love and Rationality', in R. Lamb (ed.), Love Analyzed, Boulder: Westview Press.

Nozick, R. (1989), 'Love's Bond', in The Examined life: Philosophical Meditations. New York: Simon \& Schuster.

Nussbaum, M. C. (1997), 'Love and the Individual: Romantic Rightness and Platonic Aspiration', in R. Lamb (ed.), Love Analyzed, Boulder: Westview Press.

Rorty, A. O. (1986), 'The Historicity of Psychological Attitudes: Love Is Not Love Which Alters Not When It Alteration Finds', Midwest Studies in Philosophy, 10: 399-412.

Singer, I. (1984a), The Nature of Love, Volume 1: Plato to Luther. Chicago: University of Chicago Press.

Singer, I. (1984b), The Nature of Love, Volume 2: Courtly and Romantic. Chicago: University of Chicago Press.

Singer, I. (1989), The Nature of Love, Volume 3: The Modern World. Chicago: University of Chicago Press.

Soble, A. (1990), The Structure of Love. New Haven: Yale University Press.

Solomon, R. C. (2002), 'Reasons for Love', Journal for the Theory of Social Behaviour, $32: 1$.

Wong, D. (2014), 'The Different Faces of Love in a Good Life', in C. Li and P. Ni (eds.), Moral Cultivation and Confucian Character: Engaging Joel J. Kupperman, Albany: SUNY Press. 